
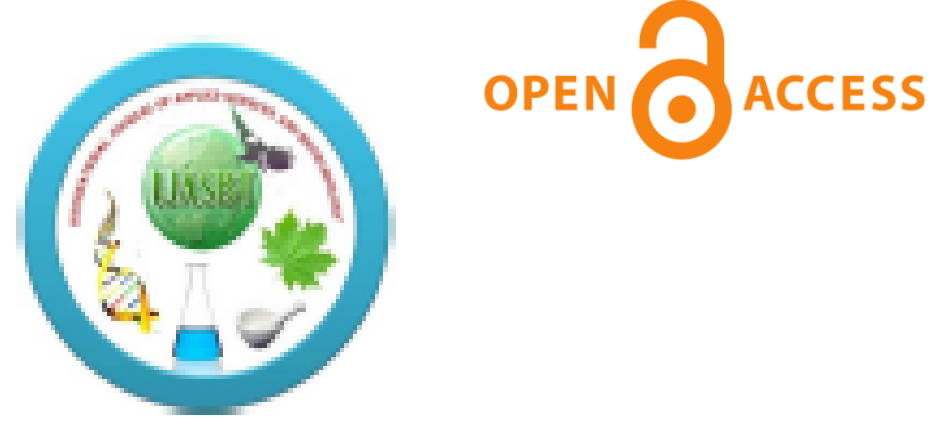

Avalable online at wwwijastbtorg.

International Journal of Applied Sciences and Biotechnology A Rapid Publishing Journal

\begin{tabular}{|c|c|c|}
\hline \multicolumn{2}{|c|}{ APPUED SCIENCES } & BIOTECHNOLOGY \\
\hline $\begin{array}{l}\text { Biochemistry } \\
\text { Molecular biology } \\
\text { Microblolowy } \\
\text { Cell biology }\end{array}$ & $\begin{array}{l}\text { Immunobiology } \\
\text { Bioinformatics } \\
\text { Nowel drug delivery rytem } \\
\text { Pharmacology }\end{array}$ & $\begin{array}{l}\text { Mierobibl biotechnolosy } \\
\text { Med laal biotechnology } \\
\text { Industrial blotechnolosy } \\
\text { Environmental biatechnolosy }\end{array}$ \\
\hline $\begin{array}{l}\text { Cytology } \\
\text { Genetics } \\
\text { Pathalosy }\end{array}$ & $\begin{array}{l}\text { Neu robilology } \\
\text { Bio-physics } \\
\text { Botany }\end{array}$ & Nanatechnology \\
\hline $\begin{array}{l}\text { Med ininal chemistry } \\
\text { Polymer sdiences } \\
\text { Analytical themistry } \\
\text { Natu ral chemistry }\end{array}$ & $\begin{array}{l}\text { Zoology } \\
\text { Allied science } \\
\text { Earth sdence }\end{array}$ & \\
\hline
\end{tabular}

If any queries or feedback, then don't hesitate to mail us at: editor.ijasbti@gmail.com 


\section{Milestones in Molecular Biology}

W hen we search the published literatures, we can see an exponential increase of literature on molecular biology in recent decades, which makes it one of the world's leading sciences. Most of the 'popular' science in the media seems superficially to be about other subjects, but, molecular biology is the indispensable platform on which almost all life and health-science discovery is based. Although, it is quite difficult to say which discovery is most important from the beginning of this subject. The actual birth of molecular biology occurred 60 years back when Watson and Crick published structure of DNA. But few of them stand out in the way that the elucidation of the genetic code or the transcriptional mechanics of the lac operon did in the late 1950s and early 1960s whereas, genetic codes are triplet was published in 1961.

In 1977, it became clear that eukaryotic genes are interrupted due to presence of exons and introns, it clarify that various portions of DNA do not show transcription and translation. In the same time the concept became clear that DNA can be sequenced.

PCR, a technique developed by Kary Mullis in 1983, is now a common and often indispensable for medical and biological research. DNA cloning for sequencing, DNA-based phylogeny, or functional analysis of genes; the diagnosis of hereditary diseases; the identification of genetic fingerprints (used in forensic sciences and paternity testing); and the detection and diagnosis of infectious diseases became easy by the development of this technique. In 1993, Mullis was awarded the Nobel Prize in Chemistry along with Michael Smith for his work on PCR.

In 1976, Walter Fiers was the first to establish the complete nucleotide sequence of a viral RNA-genome (bacteriophage MS2) and in 1977, Fred Sanger completed the first DNA-genome project of Phage $\Phi-X 174$ having 5386 base pairs only. In the mid-1990s, the first complete genome sequences all 3 domains of life were released. New sequencing technologies, such as massive parallel sequencing technique emerged as very easy over Sanger technique of sequencing in the last decade.

In 2001s, genome-wide association studies (GWAS) have documented a strong statistical association between common genetic variation at thousands of loci and more than 250 human traits. The functional effects of most GWASimplicated variants are not explained till this date. The finding that nearly $90 \%$ of these sites occur outside of protein-coding sequences suggests that many associated variants may instead have a role in gene regulation. To elucidate the genetic component underlying altered gene expression, expression quantitative trait locus (eQTL) mapping offers a powerful approach in present days. eQTLs 
are common in humans by studies in blood, skin, liver, adipose and brain. Genetic variation can also influence gene expression through alterations in splicing, non-coding RNA expression and RNA stability. Analyzing multiple tissues will be important because evaluation of the functional consequences of a disease-associated SNP is ideally performed in a disease-relevant cell context. However, for most tissue types, human bio-specimens are very difficult to obtain from living donors (for example, brain, heart and pancreas), and most eQTL studies so far have been performed with RNA isolated from immortalized lymphoblasts or lymphocytes and a few additional readily sampled tissues.

We can see the gradual increase of the biotech industry all over world, driven largely by the discoveries from molecular biology. However, the expectations for betterment of peoples need have not been fulfilled. Although, a few diseases have been diagnosed and cured using molecular means. Economy of any country in the world has not driven drastic changes due to recent achievements of discoveries. The under developed and developing countries are facing economic crisis for research and development, on the other hand, developed countries are not utilizing the all potentials of human resources available. Investment in the territories of under development and developing countries by the developed countries can provide easy and effective platform for research for development and high quality research in low cost. 